\title{
Peripheral Expression Levels of Selected Oxidative Stress-Related Genes in Alzheimer's Disease
}

\author{
Alzheimer Hastalığında Oksidatif Stres ile Ilişkili Seçilmiş Genlerin Periferik \\ Kandaki Anlatım Düzeyi
}

\author{
Pınar Köseoğlư 1,2 (D), Gamze Güven 1,2 (D), Ebba Lohmann ${ }^{3,4,5}$ (D), Haşmet Hanağası ${ }^{3}$ (D),

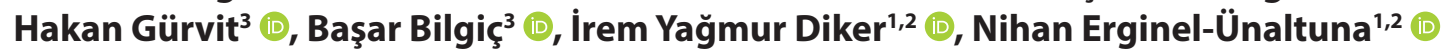

\begin{abstract}
'Department of Genetics, Aziz Sancar Institute of Experimental Medicine, Istanbul University, Istanbul, Turkey ${ }^{2}$ Graduate School of Health Sciences, Istanbul University, Istanbul, Turkey

${ }^{3}$ Behavioral Neurology and Movement Disorders Unit, Department of Neurology, Istanbul Faculty of Medicine, Istanbul University, Istanbul, Turkey ${ }^{4}$ Department of Neurodegenerative Diseases, Hertie Institute for Clinical Brain Research, University of Tübingen, Tübingen, Germany ${ }^{5} \mathrm{DZNE}$, German Center for Neurodegenerative Diseases, Tübingen, Germany
\end{abstract}

ORCID ID: P.K. 0000-0003-4681-0968; G.G. 0000-0001-8576-5843; E.L. 0000-0001-8695-7919; H.H. 0000-0001-9645-7707; H.G. 0000-0003-2908-8475; B.B. 0000-0001-6032-0856; I.Y.D. 0000-0001-9251-7354; N.E.Ü. 0000-0003-0562-0455

Cite this article as: Koseoglu P, Guven G, Lohmann E, Hanagasi H, Gurvit H, Bilgic B, Diker IY, Erginel-Unaltuna N. Peripheral expression levels of selected oxidative stress-related genes in Alzheimer's disease. Experimed 2021; 11(3): 143-8.

\begin{abstract}
Objective: The etiology of Alzheimer's disease (AD) is affected via oxidative stress. Antioxidant enzymes are extremely important in preventing reactive oxygen species (ROS) causing damage in the cell. The changes in expression levels of oxidant and antioxidant genes are key factors in cell response to oxidative stress. As a result, this study investigated the change in expression levels of specific oxidative stress related genes (solute carrier family 7 member 11 (SLC7A11), glutathione peroxidase 4 (GPX4), catalase (CAT) and acylcoa synthetase long chain family member 4 (ACSL4)) in peripheral blood of AD patients.
\end{abstract}

Material and Method: Quantitative reverse-transcription polymerase chain reaction ( $q R T-P C R$ ) was used to assess the expression levels of oxidative stress-related genes in 25 AD patients and 22 controls, and the findings were statistically evaluated.

Results: SLC7A11, GPX4, CAT, and ACSL4 gene expression levels did not vary significantly between $A D$ patients and controls. The results also showed significant negative correlation between age of onset and ACSL4 expression.

Conclusion: This is the first study that evaluated mRNA expression levels of SLC7A11, GPX4 and ACSL4 genes in AD. The results suggested that the peripheral blood expression of above-mentioned genes did not alter in AD. However, due to the small number of subjects, this findings are preliminary and should be validated with a larger number of subjects.

Keywords: Alzheimer's Disease, oxidative stress, SLC7A11, GPX4, CAT, ACSL4

\section{öz}

Amaç: Oksidatif stres, Alzheimer hastalığının (AH) etiyolojisinde önemli bir rol oynamaktadır. Antioksidan enzimler reaktif oksijen türevlerinin (ROS) hücreye zarar vermesini önlemek için çok önemlidir. Oksidan ve antioksidan enzimleri kodlayan genlerin anlatım seviyelerindeki değişimler hücrenin oksidatif strese karşı verdiği yanıtta anahtar faktördür. Bu nedenle çalışmamızda, AH hastalarının periferik kanlarında spesifik oksidatif stres ile ilişkili genlerin (solut taşıyıcı aile 7 üye 11 (SLC7A11), glutatyon peroksidaz 4 (GPX4), katalaz (CAT) ve açil-koA sentetaz uzun zincir aile üyesi 4 (ACSL4)) anlatım düzeylerindeki değişimin araştırılması amaçlanmıştır.

Gereç ve Yöntem: Periferik kan lökositlerinde oksidatif stresle ilgili genlerin ekspresyon düzeylerindeki değişiklikler $25 \mathrm{AH}$ hastası ve 22 kontrolde kantitatif ters transkripsiyon polimeraz zincir reaksiyonu (qRT-PCR) ile belirlenmiş ve sonuçlar istatistiksel olarak değerlendirilmiştir.

Bulgular: SLC7A11, GPX4, CAT ve ACSL4 genlerinin anlatım düzeyleri, AH hastaları ve kontroller arasında istatistiksel olarak bir farklılık göstermemiştir. Ayrıca, sonuçlarımız başlangıç yaşı ile ACSL4 ekspresyonu arasında anlamlı negatif bir korelasyon olduğunu göstermiştir.

Sonuç: Araştırmamız, AH hastalarının periferik kanlarında SLC7A11, GPX4 ve ACSL4 genlerinin anlatım düzeylerini değerlendiren ilk çaıışma olup, sonuçlarımız söz konusu genlerin periferik kandaki anlatımlarının AH'de değişmediğini göstermiştir. Bununla birlikte, az sayıda hasta ve kontrol nedeniyle, bu bulgular başlangıç niteliğindedir ve daha geniş çalışma gruplarında doğrulanması gerekmektedir.

Anahtar Kelimeler: Alzheimer hastalığı, oksidatif stres, SLC7A11, GPX4, CAT, ACSL4 


\section{INTRODUCTION}

Alzheimer's disease (AD) is a neurodegenerative disease marked by increasing cognitive dysfunction, as well as accumulated amyloid plaques and neurofibrillary tangles in the brain. (1). The increase in the prevalence of $A D$ is one of the major health problems. Loss of synaptic communication and neuronal death are among the main underlying causes of AD (2). However, the mechanisms that underpin neuronal death in $A D$ are not fully understood and that holds back the improvement of efficient therapeutic approaches. Data from several studies suggests that approximately $80 \%$ of AD cases are due to genetic factors, based on twin and family studies $(3,4)$. In addition to genetic factors, environmental factors are also very important in a sporadic form of $A D$, especially after the age of 65 (5). The oxidative stress is a common condition that has considerable impact on $A D$ etiology. Oxidative stress causes oxidative modifications in nuclear and mitochondrial DNA in AD. Increased reactive oxygen species (ROS) formation, mitochondrial dysfunction, an impaired antioxidant activity, or a combination of these elements are the most common causes (6). ROS can act as a signal molecule or alter gene expression of signal molecules within the cell. Increased ROS residuals may affect the molecular mechanism of synaptic activity and neurotransmission causing cognitive dysfunction (7). Also, oxidative stress is associated with the deposition of $\beta$-amyloid $(A \beta)$ plaque (8), while $A \beta$ plaque leads to the formation of free radicals and oxidative stress (9). Against oxidative stress, the body uses its own defense mechanism through antioxidants. Changes in the expressions of antioxidant enzyme genes are important for the cell response to oxidative damage (10). One of these antioxidant enzymes is glutathione peroxidase 4 (GPX4) which needs glutamate, cystine and cysteine for enzyme activation (11). Catalase (CAT), encoded by the CAT gene, is another important antioxidant enzyme that basically converts two molecules of hydrogen peroxide into one molecule of oxygen and two molecules of water in a two-step reaction (12). A study performed by Habib et al. showed catalase-amyloid interactions in neurotoxic $A \beta$ peptides stimulated oxidative stress (13). Solute carrier family 7 member 11 (SLC7A11) has an important function in the antioxidant mechanism as it supports the survival and growth of the cell by providing cystine uptake and promoting glutathione synthesis under oxidative stress (14). Ferroptosis, a recently identified mechanism of cell death, has also been shown to play a role in oxidative stress and neurodegenerative disorders in recent years. The catalytic enzyme acyl-coa synthetase long chain family member 4 (ACSL4) is involved in the ferroptosis lipid metabolism pathway. The ACSL4 establishes cell susceptibility to ferroptosis and leads to ferroptotic cell death (15).

The function of antioxidant enzymes is mostly regulated at the transcriptional level. Inability to produce sufficient antioxidant enzyme mRNA against ROS accumulation causes the cell to be unable to defend itself against oxidative stress. Variations in antioxidant gene expression levels can lead to oxidative harm in AD patients' central nervous systems (10). If oxidative stress increases in $A D$, an increase in the function of antioxidant enzymes and gene expressions can be expected in $A D$ patients. Yet, conflicting results have been obtained in postmortem studies in AD brains on antioxidant gene expressions (16) and there are few studies showing the alteration of antioxidant gene expression levels in AD (10). This study investigated whether GPX4, CAT, SLC7A11 and ACSL4 gene expressions, which are known to be associated with oxidative stress, changed in the peripheral blood of AD patients.

\section{MATERIAL AND METHOD}

\section{Study Population}

The research involved 25 AD patients and 22 healthy controls who had no background of significant neurologic or mental illness. Participants were recruited from Istanbul Faculty of Medicine, Istanbul University in the Behavioral Neurology and Movement Disorders Unit of Neurology Department. The diagnosis of dementia was made according to the Diagnostic and Statistical Manual of Mental Disorders (DSM-IV) and the National Institute of Neurological and Communicative Disorders and Stroke and Alzheimer's disease and Related Disorders (NINCDS-ADRDA) criteria. All participants signed informed consent forms. The Istanbul University's Ethics Committee gave approval to the study's procedures.

\section{Genetic Analysis}

Total RNA was collected from leukocytes in the peripheral blood using trizol reagent (Thermo Fisher Scientific, MA, USA) according to the manufacturer's instructions. The iScript ${ }^{\mathrm{TM}}$ CDNA synthesis kit (Bio-Rad, CA, USA) was used to synthesize cDNA from $1 \mu \mathrm{g}$ of total RNA according to the manufacturer's protocol. The SYBR Green I Assay (Thermo Fisher Scientific, MA, USA) was used in a qRT-PCR on the Lightcycler 480 Real-Time PCR system (Roche, Basel, Switzerland). The data was normalized using GAPDH as the housekeeping gene, and the relative expression levels of SLC7A11, GPX4, CAT, and ACSL4 genes were calculated using the $2^{-\triangle \triangle C T}$ method.

\section{Data Analysis}

Expression levels of SLC7A11, GPX4, CAT and ACSL4 among groups were compared by the non-parametric two-tailed Mann-Whitney U test. Spearman's rho test was performed to investigate correlations between SLC7A11, GPX4, CAT and ACSL4 mRNA expressions and age, age at onset, and mini mental state examination (MMSE) scores. The categorical variables were compared using Fisher's exact test. A p value was considered statistically significant for less than 0.05 . All statistical analysis was performed using SPSS Statistics 23.0 software (IBM Corp., USA).

\section{RESULTS}

Table 1 summarizes the descriptive characteristics of the study population. There was a significant age gap between AD patients and controls, and the overall MMSE score in patients was significantly lower than in controls (Table 1).

The expression levels of SLC7A11, GPX4, CAT and ACSL4 genes 
Table 1. Descriptive characteristics of study population.

\begin{tabular}{|c|c|c|c|}
\hline & $\begin{array}{c}\text { AD }(n=25) \\
(\text { mean } \pm S D)\end{array}$ & $\begin{array}{l}\text { Control }(n=22) \\
(\text { mean } \pm S D)\end{array}$ & p-value \\
\hline Age, years, (range) & $77.20 \pm 5.058,(67-89)$ & $73.90 \pm 6.265,(66-91)$ & 0.035 \\
\hline Age of onset, years, (range) & $72.20 \pm 5.848,(65-84)$ & - & \\
\hline Gender, \% (n) & & & 0.452 \\
\hline Male & $48 \%(13)$ & $59.1 \%(13)$ & \\
\hline Female & $52 \%(12)$ & $40.9 \%(9)$ & \\
\hline MMSE score (range) & $18.39 \pm 5.255,(10-26)$ & $27.72 \pm 3.232,(17-30)$ & $<0.0001$ \\
\hline
\end{tabular}

in leukocyte did not vary significantly between $A D$ patients and control subjects. As shown in Figure 1a, the SLC7A11 expression level in $A D$ (mean $\pm S E M ; 1.21 \pm 0.18$ ) was similar to
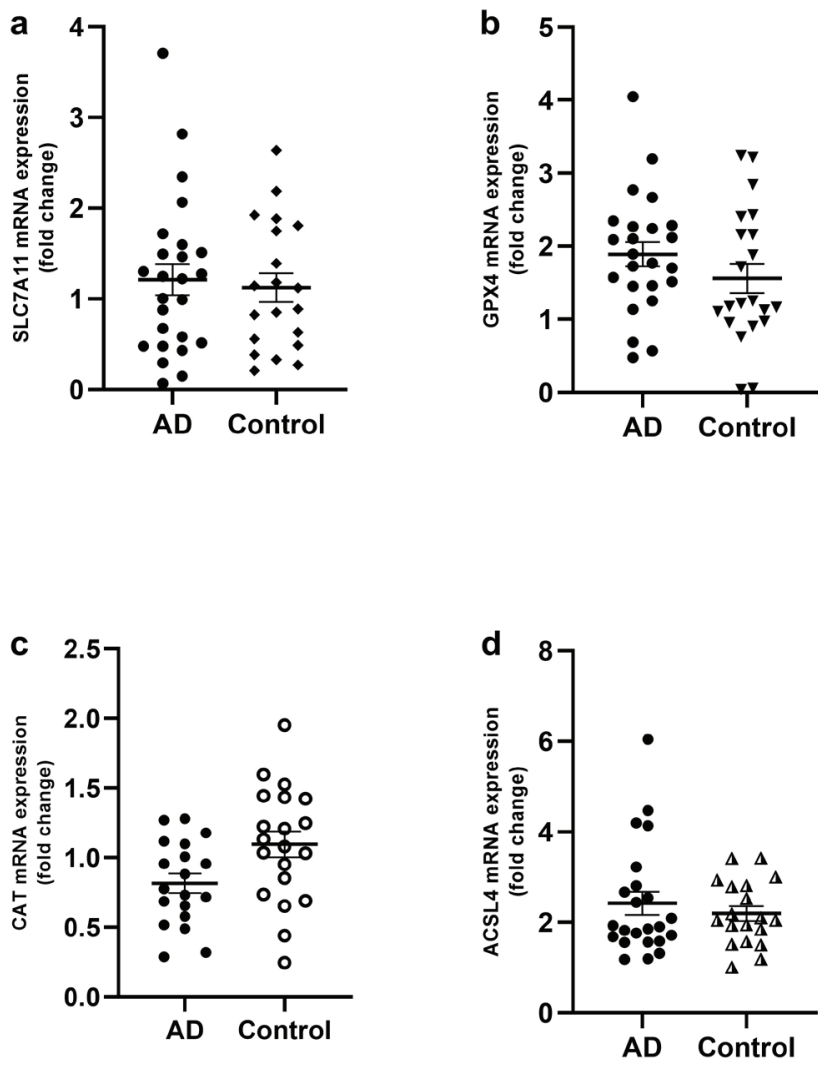

Figure 1. mRNA expression levels in study population (a) SLC7A11 expression in AD and control subjects (b) GPX4 expression in $A D$ and control subjects (c) CAT expression in $\mathrm{AD}$ and control subjects (d) ACSL4 expression in AD and control subjects. Data are presented with mean $\pm S E M, A D$ Alzheimer disease, SEM standard error of the mean. controls (1.12 $\pm 0.16, p=0.819)$. Although GPX4 expression seems to be increased in $A D(1.89 \pm 0.17)$ as compared to controls (1.56 \pm 0.20$)$, no significant difference was found $(p=0.207$, Figure $1 \mathrm{~b}$ ). In addition, lower CAT expression was observed in AD patients $(0.89 \pm 0.10)$ as compared to controls $(1.09 \pm 0.09)$ without any significance ( $p=0.72$, Figure 1c). Finally, the ACSL4 expression appears to be higher in AD patients $(2.42 \pm 0.25)$ as compared to controls $(2.19 \pm 0.16$, Figure $1 d)$ without statistical significance $(p=0.889)$.

In $\mathrm{AD}$ patients, a correlation analysis was used to show the relationship between age, age of onset, MMSE score, and the expression levels of SLC7A11, GPX4, ACSL4 and CAT genes. The ACSL4 expression and age at onset had a significant negative correlation, according to our findings ( $r=-0.458, p=0.028$; Figure 2). Other gene expressions were found to have no significant correlation with age, age of onset, or MMSE score in AD patients (Supplementary Figure 1 and 2).

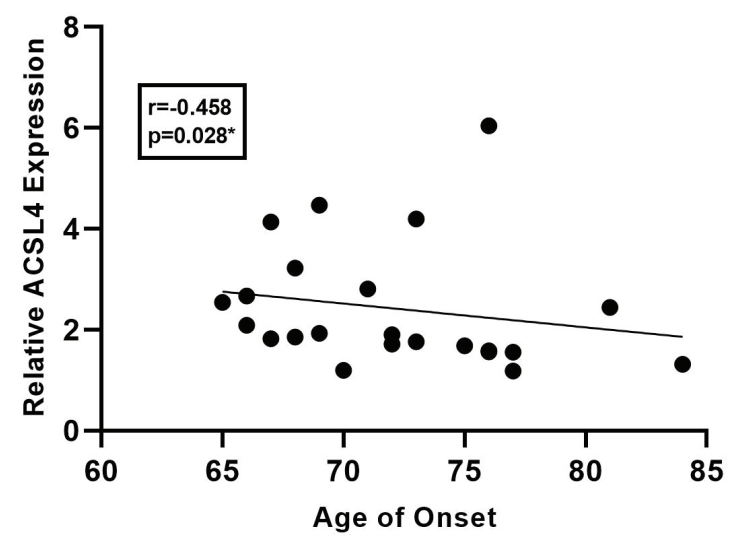

Figure 2. Correlation between ACSL4 mRNA expression and age of onset in AD patients. 


\section{DISCUSSION}

Several reports have shown the relationship between oxidative stress and AD etiology (7-9). Oxidative stress tends to increase in the brain with age. Even so, the role of oxidative stress in the etiology of $A D$ is still unknown. The main goal of this research was to investigate whether the expression levels of specific oxidative stress-related genes could be identified in peripheral blood of AD patients. For this purpose, a study was made of the peripheral expression levels of SLC7A11, GPX4, CAT and ACSL4 genes that were known to play a role in oxidative stress.

Cell death by apoptosis is known to occur in response to oxidative stress, and GPX4 has been identified as a key regulator of apoptosis in response to oxidative stress (17). In transgenic mice, increased expression of GPX4 preserves neurons from oxidative stress and amyloid toxicity (17). Furthermore, in a study by Hambright et al., inactivation of GPX4 gene in neuronal cells promotes hippocampal neurodegeneration and cognitive dysfunction in a mouse model (18). Studies investigating the relationship between GPX4 and AD were limited to animal models, so far there has been only one study in humans, and that study explored the effect of GPX4 polymorphism on episodic memory (19). Therefore, this is the first study to investigate GPX4 gene expression levels in AD patients. The results showed that GPX4 expression increased in the peripheral blood of AD patients, although it was not statistically significant. This increase may be the result of neuroprotective effect of GPX4 in AD.

SLC7A11 plays a crucial role in antioxidant protection by mediating cystine uptake, promoting glutathione synthesis, and sustaining cell viability against oxidative stress conditions (14). In the central nervous system (CNS), glutamate export is particularly important since it is a non-vesicular pathway of release for this excitatory neurotransmitter, which can play a role in neuronal signaling or excitotoxic pathology (20). One study showed that by releasing glutamate through microglia increased $A \beta$ toxicity which suggested that since the SLC7A11 gene was expressed not only in cultured microglia but also in the reactive microglia inside or around amyloid plaques in transgenic mice, this could be important to $A \beta$ toxicity in $A D$ (21). In a study conducted in the peripheral blood of schizophrenia patients, the significant reduction of SLC7A11 gene expression supports the hypo-glutamatergic neurotransmission hypothesis in the pathogenesis of schizophrenia and the role of SLC7A11 in neurological diseases (22). However, SLC7A11 gene expression levels in the peripheral blood of AD patients has not been investigated so far. Although the results showed that the peripheral blood expression of SLC7A11 did not change in AD, this should be considered preliminary because of the small size and should be further investigated in a larger study.

Catalase is an antioxidant enzyme which is involved in oxidative stress mechanism (12). It has been suggested that catalase deficiency or degradation is implicated in the pathogenesis of degenerative diseases including diabetes mellitus, cancer, $A D$, Parkinson's disease and hypertension which increase in fre- quency with age (23). In the analysis of different brain regions of $A D$ patients, Aksenov et al. found a substantial increase in CAT expression in brain regions affected by AD pathology (9). This suggested that this antioxidant enzyme could play an important role in protecting CNS cells from oxidative stress in AD. Also, the same study showed that an increased expression of $C A T$ leads to an increased tolerance of cultured neural cells to $A \beta$ toxicity (10). In another study conducted in late-onset $A D$ (LOAD) patients, it was observed that CAT gene expression levels in peripheral blood were significantly decreased compared to the controls, but the erythrocyte CAT enzymatic activity was significantly increased in LOAD patients. This suggests that even as the expression of antioxidant genes decreased, their enzymatic activity was not affected (24). Consistent with that study, we observed a decreased mRNA expression of CAT in $A D$ patients but without statistical significance. However, since CAT enzyme activity was not measured, a comparison could not be made like the study of González-Mundo et al.

Considering the fact that the brain is the fattiest organ after adipose tissue, ACSL4 is regarded as an important enzyme for neurodegenerative diseases due to its role in lipid metabolism although it has not been fully investigated in AD (25). An in vitro study of embryonic stem cells showed that the nerve growth factor, retinoic acid induced neuronal differentiation, and neurite growth were weakened by a knockout of the ACSL4 gene (26). This study showed a non-significantly decreased expression level of ACSL4 in AD patients, also a correlation analysis pointed out that the expression of ACSL4 decreased with increasing age of onset. The fact that AD patients had higher ACSL4 expression levels may support the assumption that a lipid metabolism pathway is involved in the pathogenesis of oxidative stress in AD. Since our study is the first investigating the ACSL4 expression levels in AD patients, it is necessary to replicate our findings in larger patient-control groups and to support by further in vitro studies.

Aging is a major risk factor for $A D$, and it is known that the expression of several genes are altered during aging. Many studies have shown that the expression of various genes involved in DNA repair, energy metabolism, oxidative stress response, and synaptic activity changes with aging (27). Although limited to animal studies, GPX4 and SLC7A11 gene expressions have been shown to alter with age, while the effect of age on ACSL4 gene expression is unknown $(28,29)$. Also, a study by Tatone et al. showed that the CAT mRNA levels were significantly lower in women over the age of 38 (30). In this study, we did not find any correlation between age and the expression of studied genes. This may suggest that age may not influence the expression of these genes, but it should not be ruled out since this research was conducted with a small study group. Although the age of the patients and controls was similar, we found a statistically significant difference between them. However, no significant effect of age was observed in correlation analysis.

Our study has several limitations. First, the current study was conducted using a small sample size. Second, the activities 
of enzymes that are products of studied genes could not be measured. Therefore, the ability to investigate the relationship between extracellular enzymatic activity and mRNA expression levels was hampered. Lastly, considering AD is a CNS disease, the whole blood-based mRNA analysis is a limitation factor. Future research should focus on mRNA expression in brain tissues from Alzheimer's patients and in vitro cell cultures. The present study laid the groundwork for future research into oxidative stress related gene expressions in AD.

\section{CONCLUSION}

In conclusion, the results showed that peripheral blood expressions of the GPX4, SLC7A11, CAT and ACSL4 genes were not altered in AD. However, further studies investigating the expression of these genes in brain tissue rather than peripheral blood will be more informative to elucidate their roles in AD etiology.

Ethics Committee Approval: The Istanbul University's Ethics Committee gave approval to the study's procedures. All participants signed informed consent forms.

Peer-review: Externally peer-reviewed.

Author Contributions: Conception/Design of Study - N.E.Ü., P.K., G.G.; Data Acquisition - E.L., H.H., B.B., H.G.; Data Analysis/Interpretation - P.K., I.Y.D.; Drafting Manuscript - P.K., G.G.; Critical Revision of Manuscript N.E.Ü., H.H., B.B., H.G., E.L., I.Y.D.; Final Approval and Accountability - P.K., G.G., N.E.Ü., H.H., B.B., H.G., E.L, I.Y.D.

Conflict of Interest: The authors have no conflict of interest to declare.

Financial Disclosure: This study was funded by Scientific Research Projects Coordination Unit of Istanbul University (Project numbers TYL2019-33597 and TSA-2017-25862).

Etik Komite Onayı: Çalışma için İstanbul Üniversitesi Etik Kurulu'ndan onay alınmıştır. Tüm katılımcılar bilgilendirilmiş onam formunu imzalamışlardılar.

\section{Hakem Değerlendirmesi: Dış bağımsız.}

Yazar Katkıları: Çalışma Konsepti/Tasarım - N.E.Ü., P.K., G.G.; Veri Toplama - E.L., H.H., B.B., H.G.; Veri Analizi/Yorumlama - P.K., I.Y.D.; Yazı Taslağı - P.K., G.G.; İçeriğin Eleştirel İncelemesi - N.E.Ü., H.H., B.B., H.G., E.L., I.Y.D.; Son Onay ve Sorumluluk - P.K., G.G., N.E.Ü., H.H., B.B., H.G., E.L, I.Y.D.

Çıkar Çatışması: Yazarlar çıkar çatışması bildirmemişlerdir.

Finansal Destek: Bu çalışma İstanbul Üniversitesi Bilimsel Araştırma Projeleri Koordinasyon Birimi tarafından desteklenmiştir (Proje numaraları: TYL-2019-33597 ve TSA-2017-25862).

\section{REFERENCES}

1. Mantzavinos V, Alexiou A. Biomarkers for Alzheimer's Disease diagnosis. Curr Alzheimer Res 2017; 14(11): 1149-54. [CrossRef]

2. Mayeux R, Stern Y. Epidemiology of Alzheimer disease. Cold Spring Harb Perspect Med 2012; 2(8): a006239. [CrossRef]
3. Gatz M, Reynolds CA, Fratiglioni L, Johansson B, Mortimer JA, Berg $S$, et al. Role of genes and environments for explaining Alzheimer disease. Arch Gen Psychiatry 2006; 63(2): 168-74. [CrossRef]

4. Tanzi RE. The genetics of Alzheimer disease. Cold Spring Harb Perspect Med 2012; 2(10): a006296. [CrossRef]

5. Van Cauwenberghe C, Van Broeckhoven C, Sleegers K. The genetic landscape of Alzheimer disease: clinical implications and perspectives. Genet Med2016; 18(5): 421-30. [CrossRef]

6. Nita M, Grzybowski A. The Role of the reactive oxygen species and oxidative stress in the pathomechanism of the age-related ocular diseases and other pathologies of the anterior and posterior eye segments in adults. Oxid Med Cell Longev 2016; 2016: 3164734. [CrossRef]

7. Tönnies E, Trushina E. Oxidative stress, synaptic dysfunction, and Alzheimer's Disease. J Alzheimers Dis 2017; 57(4): 1105-21. [CrossRef]

8. Chen K, Kazachkov M, Yu PH. Effect of aldehydes derived from oxidative deamination and oxidative stress on $\beta$-amyloid aggregation; pathological implications to Alzheimer's disease. J Neural Transm 2007; 114(6): 835-9. [CrossRef]

9. Mayes J, Tinker-Mill C, Kolosov O, Zhang H, Tabner BJ, Allsop D. $\beta$-Amyloid fibrils in Alzheimer Disease are not inert when bound to copper ions but can degrade hydrogen peroxide and generate reactive oxygen species. J Biol Chem 2014; 289(17): 12052-62. [CrossRef]

10. Aksenov MY, Tucker HM, Nair P, Aksenova MV, Butterfield DA, Estus $\mathrm{S}$, et al. The expression of key oxidative stress-handling genes in different brain regions in Alzheimer's disease. J Mol Neurosci 1998; 11(2): 151-64. [CrossRef]

11. Conrad M, Friedmann Angeli JP. Glutathione peroxidase 4 (Gpx4) and ferroptosis: what's so special about it? Mol Cell Oncol 2015; 2(3): e995047-e. [CrossRef]

12. von Ossowski I, Hausner G, Loewen PC. Molecular evolutionary analysis based on the amino acid sequence of catalase. J Mol Evol 1993; 37(1): 71-6. [CrossRef]

13. Habib LK, Lee MTC, Yang J. Inhibitors of catalase-amyloid interactions protect cells from beta-amyloid-induced oxidative stress and toxicity. J Biol Chem 2010; 285(50): 38933-43. [CrossRef]

14. Liu X, Zhang Y, Zhuang L, Olszewski K, Gan B. NADPH debt drives redox bankruptcy: SLC7A11/xCT-mediated cystine uptake as a double-edge sword in cellular redox regulation. Genes \& Diseases In press 2020. [CrossRef]

15. Yan N, Zhang J-J. The Emerging roles of ferroptosis in vascular cognitive impairment. Front Neurosci 2019; 13(811). [CrossRef]

16. Bowling AC, Beal MF. Bioenergetic and oxidative stress in neurodegenerative diseases. Life Sci 1995; 56(14): 1151-71. [CrossRef]

17. Ran Q, Gu M, Van Remmen H, Strong R, Roberts JL, Richardson A. Glutathione peroxidase 4 protects cortical neurons from oxidative injury and amyloid toxicity. J Neurosci Res 2006; 84(1): 202-8. [CrossRef]

18. Hambright WS, Fonseca RS, Chen L, Na R, Ran Q. Ablation of ferroptosis regulator glutathione peroxidase 4 in forebrain neurons promotes cognitive impairment and neurodegeneration. Redox Biol 2017; 12: 8-17. [CrossRef]

19. da Rocha TJ, Silva Alves M, Guisso CC, de Andrade FM, Camozzato A, de Oliveira AA, et al. Association of GPX1 and GPX4 polymorphisms with episodic memory and Alzheimer's disease. Neurosci Lett 2018; 666: 32-7. [CrossRef]

20. Bridges RJ, Natale NR, Patel SA. System xc- cystine/glutamate antiporter: an update on molecular pharmacology and roles within the CNS. Br J Pharmacol 2012; 165(1): 20-34. [CrossRef] 
21. Qin S, Colin C, Hinners I, Gervais A, Cheret C, Mallat M. System $\mathrm{XC}$ - and apolipoprotein $\mathrm{E}$ expressed by microglia have opposite effects on the neurotoxicity of amyloid-beta peptide 1-40. J Neurosci 2006; 26(12): 3345-56. [CrossRef]

22. Lin $\mathrm{C}-\mathrm{H}$, Lin $\mathrm{P}-\mathrm{P}$, Lin $\mathrm{C}-\mathrm{Y}$, Lin $\mathrm{C}-\mathrm{H}$, Huang $\mathrm{C}-\mathrm{H}$, Huang $\mathrm{Y}-\mathrm{J}$, et al. Decreased mRNA expression for the two subunits of system xc-, SLC3A2 and SLC7A11, in WBC in patients with schizophrenia: Evidence in support of the hypo-glutamatergic hypothesis of schizophrenia. J Psychiatr Res 2016; 72: 58-63. [CrossRef]

23. Nandi A, Yan L-J, Jana CK, Das N. Role of catalase in oxidative stress- and age-associated degenerative diseases. Oxid Med Cell Longev 2019; 2019: 9613090. [CrossRef]

24. González-Mundo I, Pérez-Vielma NM, Gómez-López M, Fleury A, Correa-Basurto J, Rosales-Hernández MC, et al. DNA methylation of the RE-1 silencing transcription factor in peripheral blood mononuclear cells and gene expression of antioxidant enzyme in patients with late-onset Alzheimer disease. Exp Gerontol 2020; 136: 110951. [CrossRef]

25. Fernandez RF, Ellis JM. Acyl-CoA synthetases as regulators of brain phospholipid acyl-chain diversity. Prostaglandins Leukot Essent Fatty Acids 2020; 161: 102175. [CrossRef]
26. Cho Y-Y. A novel role of brain-type ACS4 isotype in neuronal differentiation. Biochem Biophys Res Commun 2012; 419(3): 505-10. [CrossRef]

27. Işıldak U, Somel M, Thornton JM, Dönertaş HM. Temporal changes in the gene expression heterogeneity during brain development and aging. Sci Rep 2020; 10(1): 4080. [CrossRef]

28. Zheng Y, Ritzenthaler JD, Burke TJ, Otero J, Roman J, Watson WH. Age-dependent oxidation of extracellular cysteine/cystine redox state (Eh(Cys/CySS)) in mouse lung fibroblasts is mediated by a decline in Slc7a11 expression. Free Radic Biol Med 2018; 118: 1322. [CrossRef]

29. Thiab NR, King N, McMillan M, Alghamdi OAS, Jones GL. Age-related protein and mRNA expression of glutathione peroxidases (GPx) and Hsp-70 in different regions of rat kidney with and without stressor. AIMS Mol Sci 2016; 3(2): 125-37. [CrossRef]

30. Tatone C, Carbone MC, Falone S, Aimola P, Giardinelli A, Caserta $D$, et al. Age-dependent changes in the expression of superoxide dismutases and catalase are associated with ultrastructural modifications in human granulosa cells. Mol Hum Reprod 2006; 12(11): 655-60. [CrossRef] 